\title{
LAPSIPERHEIDEN KOTITALOUDEN STRATEGIAT TALOUDELLISEN EPÄVARMUUDEN JA PERHEPOLIITTISTEN MUUTOSTEN AIKANA
}

Marja Lindberg: VTM, sosiaalipolitiikean jatko-opiskelija, Abo Akademi

Janne Autto: YTT, sosiologian apulaisprofessori, Lapin yliopisto

Mikael Nygård: VTT, sosiaalipolitiikean professori, Abo Akademi

marja.lindberg@abo.fi,janne.autto@ulapland.fi,mikael.nygard@abo.fi

Janus vol. 27 (1) 2019, 3-20

Tiivistelmä

\section{(J) J a II S}

VERTAISARVIOITU
KOLLGIAT GRANSKAD
PEER-REVIEWED
www. tsv.fiftunnus

Vuosien 2007-2008 talouskriisin jälkeinen hidas talouskasvu, epävarmat työmarkkinat ja säästötoimenpiteet, kuten lapsilisien leikkaus, ovat heikentäneet perheiden taloudellista turvaa ja ajaneet lapsiperheitä köyhyyden, terveyserojen ja erilaisen pahoinvoinnin riskialueille. Artikkelissa analysoimme lapsiperheiden arjessaan kehittämiä selviytymistapoja kotitalouden strategioiden (household strategies) sekä Bourdieun pääoman käsitteiden avulla. Artikkelin aineisto koostuu pohjanmaalaisten suomen- ja ruotsinkielisten lapsiperheiden hastatteluista. Tulosten perusteella julkisille palveluille ja tuille vaihtoehtoisten kotitalouden strategioiden merkitys on ilmeinen perheiden arjessa selviämisen kannalta. Strategiat voidaan jakaa Bourdieun erottelemien pääomien mukaisesti sosiaaliseen verkostoon, taistelutahtona ilmenevään kulttuuriseen pääomaan sekä taloudellisiin järjestelyihin.

\section{JOHDANTO}

Suomen katsotaan yleensä kuuluvan pohjoismaisen hyvinvointimallin regiimiin. Suomen yhteiskunnallista kehitystä ovat kuitenkin 1990-luvun lamasta lähtien leimanneet säästöpolitiikka ja leikkaukset, jotka ovat kohdistuneet erityisesti lapsiperheisiin. Taloudelliset lamakaudet 1990-luvulla ja vuosien 2007-2008 finanssikriisin jälkeen vaikuttivat negatiivisesti lapsiperheiden hyvinvointiin (Lammi-Taskula \& Karvonen 2014; Ahrendt ym. 2015; Karvonen \& Salmi 2016) sekä heidän luottamukseensa yhteiskuntaan (Liikanen 2017). 1990-luvun talouskriisin aikaan sopeuttamistoimina tehdyt leikkaukset lapsiperheiden peruspalveluihin, kuten lastensuojeluun ja päivähoitoon (Sund- man 2016), sekä perhetukien, kuten lapsilisien ja kotihoidontukien leikkaukset sekä verotuksen lapsivähennysten poisto, vaikeuttivat monien lapsiperheiden elämää (Kiander 2001). Lapsilisiä leikattiin edelleen vuosina 2014 ja 2016 (PeVL 2014; Eduskunta 2016), ja niiden keskimääräinen reaaliarvo on laskennut 30 prosenttia vuodesta 1994 (Eskelinen \& Sironen 2017). Samalla työmarkkinoiden epävarmuuden ja syrjäytymisuhan voimistuminen sekä muutokset perhesuhteissa, kuten yksinhuoltajatalouksien yleistyminen (Kautto 2001), ovat lisänneet julkisten palvelujen ja tuen tarvetta (Julkunen 2017).

Kasvaneet tuloerot ja erityisesti lapsiperheiden keskimääräisestä jälkeen jäänyt tulokehitys ovat olleet omiaan 
lisäämään perheiden pahoinvointia ja siten vaikuttaneet näiden kokemuksiin hyvinvoinnista. Pahoinvointi on kasautunut erityisesti yksinhuoltaja- ja monilapsisiin perheisiin, pienituloisuuden määrä on lähes kaksinkertaistunut ja lapsiköyhyys on kolminkertaistunut vuoden 1995 jälkeen (Lammi-Taskula \& Salmi 2010). Useat tutkimukset (esim. Leinonen 2004; Salmi \& LammiTaskula 2014; Ahrendt ym. 2015) ovat osoittaneet, että eriarvoisuuden kuilu on kasvanut tuloerojen suurenemisen myötä. Julkinen sosiaaliturva ja palvelujärjestelmä eivät ole enää pystyneet vastaamaan lapsiperheiden tarpeisiin, minkä vuoksi perheet ovat joutuneet turvautumaan kolmannen sektorin apuun (Teperi ym. 2006; Grönlund \& Juntunen 2006; Kinnunen 2009; ks. myös Törrönen 2012) sekä omiin sosiaalisiin verkostoihinsa (esim. Liikanen 2017).

Myös epävarmuuden lisääntyminen työmarkkinoilla, kuten pätkätyöt ja työttömyyden uhka, sekä arjen jaksamisen haasteellisuuden kasvaminen vaikuttavat kielteisesti lapsiperheiden hyvinvointiin ja heidän kokemaansa luottamukseen viranomaisia ja valtiota kohtaan (esim. Liikanen 2017; Lainiala 2014; Leinonen 2004; Törrönen 2014). Luottamuksen heikkeneminen lisää tarvetta perheen sisäisille ratkaisuille, joihin perhe voi luottaa ja turvautua hyvinvointinsa varmistamisessa. Aikaisemmat tutkimukset ovat tuoneet esiin esimerkiksi sosiaalisen verkoston keskeisen merkityksen perheiden kohdatessa erilaisia riskejä ja vastoinkäymisiä arjessaan, kuten esimerkiksi työmarkkinoiden epävarmuutta, parisuhdeongelmia sekä taloudellisen toimeentulon ja arjessa jaksamisen haasteita (Lammi-
Taskula \& Karvonen 2014; Leinonen 2004; Törrönen 2014; Efendic ym. 2017).

Tähänastisten hyvinvointivaltion muutosta lapsiperheiden näkökulmasta tarkastelevien tutkimusten pääpaino on ollut kvantitatiivisessa tutkimuksessa ja tarkastelun kohteena lähinnä perheissä esiintyvät huolet ja kohdatut vaikeudet, joita taloudellinen epävarmuus tuottaa (esim. Halme \& Perälä 2014; Salmi ym. 2014). Laadulliset tutkimukset ovat puolestaan kohdistuneet esimerkiksi äitien arjessa selviämiseen (Krok 2009) ja keskittyneet koko perheiden sijasta yksittäisiin perheenjäseniin.

Tässä artikkelissa tutkimme lapsiperheiden ja hyvinvointivaltion muutosten kohtaamista kotitalouden strategioiden näkökulmasta. Kansainvälisissä tutkimuksissa kotitalouden strategioiden käsitteellä (household strategies) on viitattu juuri perheen sisäisiin järjestelyihin, joiden avulla on tarkoitus selvitä perheen hyvinvointia uhkaavista riskeistä (esim. Katz-Gerro ym. 2017). Strategian käsitteellä voidaan viitata paitsi yksilöiden myös perheiden tai kotitalouksien elämänvalintoihin ja -ratkaisuihin niin arjessa kuin laajemmassa kulttuurisidonnaisessa mielessä. Jälkimmäisellä tarkoitetaan kulttuuriin kuuluvia opittuja tapoja ja strategioita, kuten esimerkiksi sosiaalisen verkoston hyödyntämistä (Wallace 2002; Cveticanin ym. 2014).

Aiemmissa tutkimuksissa (esim. Cveticanin ym. 2014; Cveticanin \& Lavric 2017) kotitalouden strategioiden kuvaamisessa on käytetty Pierre Bourdieun sosiaalisen kentän ja habituksen käsitteitä sekä tarkasteltu perheiden 
rakentamia selviytymisstrategioita näiden yhteiskuntaluokan tai kulttuurisen perimän näkökulmista. Tutkimusten painotus on ollut kotitalouksien taloudellisissa strategioissa, joissa on nojattu sekä taloudelliseen että sosiaaliseen pääomaan ja tarkasteltu esimerkiksi kotitalouksien ja erityisesti naisten työllistymistä sekä sosiaaliselta verkostolta saatua taloudellista tukea. Kulttuurisen pääoman yhteydessä on yleensä painotettu sosiaalisen kentän merkitystä ja kulttuurista perimää, toimijoiden kasvatuksellista taustaa. Tässä artikkelissa täydennämme kotitalouden strategioiden käsitettä tarkastelemalla lapsiperheiden hyvinvointia sosiaalisen, kulttuurisen ja taloudellisen pääoman näkökulmista siten, että laajennamme kotitalouden strategiat käsittämään taloudellisen näkökulman lisäksi myös lapsiperheiden muun arjessa jaksamisen, psyykkisen ja sosiaalisen hyvinvoinnin. Kiinnitämme huomiota myös kulttuuriseen pääomaan yhtenä kotitalouden strategioiden muotona ja erityisesti perheiden taisteluna oikeuksiensa puolesta.

Lapsiperheiden taloudellisten tilanteiden, arjessa jaksamisen ja heidän subjektiivisten hyvinvointikokemustensa tutkiminen on tärkeää ainakin kahdesta eri syystä. Ensinnäkin on syytä tuoda esiin lapsiperheiden kokemukset hyvinvoinnista taloudellisen kriisin aikana ja tarkastella, miten taloudelliset ja julkisten palvelujen muutokset ovat vaikuttaneet lapsiperheiden arkipäivään. Toiseksi tarvitaan tietoa siitä, vastaavatko julkiset tukitoimet lapsiperheiden tarpeisiin ja millaiset strategiat auttavat heitä selviytymään arjessa julkisten tukien ja palveluiden ollessa riittämättömiä. Näistä lähtökohdista tapahtuvan tutkimuksen avulla on mahdollista tuoda esille lapsiperheiden kokemukset siitä, millaisena arki heille itselleen näyttäytyy ja saada heidän äänensä kuuluviin (ks. Autto \& Nygård 2015; van Oorschot 2007). Tässä tehtävässä laadullinen tutkimusote on luonteva, lapsiperheiden yksilöllisten tilanteiden syvemmän tarkastelun mahdollistava valinta.

Artikkelimme perustuu suomen- ja ruotsinkielisten pohjanmaalaisten (ns. vanha Vaasan läänin alue eli Keski- ja Etelä-Pohjanmaa sekä Pohjanmaan rannikkoseutu) lapsiperheiden haastatteluihin. Perheistä haastatteluihin osallistuivat joko perheen vanhemmat yhdessä tai äiti tai isä yksinään. Suurimmaksi osaksi haastatteluihin osallistuivat äidit. Tästä huolimatta kaikissa haastatteluissa keskusteltiin nimenomaan koko perheen ratkaisuista hyvinvointinsa varmistamiseksi. Perheille ei asetettu tiukkoja osallistumiskriteereitä, vaan haastateltavaksi pyydettiin perheitä, joilla olisi "tarina kerrottavanaan". Toiveenamme oli tavoittaa monipuolisesti erilaisia perheitä voidaksemme tarkastella perheiden pärjäämistä myös muutoin kuin taloudellisesta näkökulmasta. Aineistossa on näin ollen mukana perheitä eri tuloluokista, yksinhuoltajaperheistä kahden työssäkäyvän vanhemman perheisiin. Osassa perheitä koettiin muun muassa työttömyyttä, sairautta, köyhyyttä ja eriarvoisuutta. Aineistossa on kuitenkin myös perheitä, joilla ei ollut suuria taloudellisia huolia, mutta jotka silti tunsivat turvattomuutta ja epävarmuutta yhteiskunnallista kehitystä kohtaan. 
KOTITALOUdEN STRATEGIAT JA PÄÄOMAT

Tutkimuksemme teoreettinen viitekehys perustuu kotitalouden strategioiden käsitteeseen (ks. Katz-Gerro ym. 2017; Wallace 2002) sekä Bourdieun pääoman käsitteeseen (Bourdieu 1986). Kotitalouden strategioita on alun alkaen käytetty erityisiä sosiaalisia riskejä kohtaavien ryhmien voimavarojen ja selviytymisstrategioiden kuvaamisessa. Laajemmassa kaikkia kotitalouksia koskevassa mittakaavassa käsitettä käyttivät ensimmäisenä Raymond E. Pahl ja Jonathan Gershuny (Gershuny 1978; Gershuny \& Pahl 1979; Pahl 1984; Pahl 1980; Wallace \& Pahl 1986).

Kotitalouden strategioiden merkityksen korostumiseen ovat vaikuttaneet yhteiskunnalliset muutokset, erityisesti naisten entistä aktiivisempi osallistuminen työelämään ja tätä seurannut perheen perinteisen roolijaon murtuminen. Ne korostuvat erityisesti äkillisissä yhteiskunnallisissa muutoksissa, joiden myötä perheet kohtaavat enenevässä määrin sosiaalisia riskejä ja epävarmuutta. Lisäksi kotitalouden strategioiden merkitys korostuu perheen taloudellisen tukiverkon painottuessa epävirallisten verkostojen (perhe/suku) varaan. (Wallace 2002.)

Kotitalouden strategioiden käsitettä on käytetty kansainvälisissä tutkimuksissa kuvaamaan tapoja vastata sosiaalisiin riskeihin yhteiskunnan tuen ollessa riittämätöntä. Kotitalouden strategioiden merkitys on riippuvainen hyvinvointiregiimistä sekä yhteiskunnallisesta ja kulttuurisesta kontekstista (Wallace 2002). Käsitettä on käytetty niin sanotuissa konservatiivisen ja liberaalin hyvinvointiregiimin malleissa, joissa julkiset etuudet ovat perustuneet ansiotyöhön ja sosiaalituki ollut tarjolla vain kaikkein huono-osaisimmille. Näissä konteksteissa kotitalouden strategioiden on todettu olevan oleellinen selviytymiskeino tilanteissa, joissa toimijan koulutustaso tai sosiaalinen asema on heikko (esim. Fontaine \& Schlumbohm 2000; Cveticanin 2012; Wallace 2002; Katz-Gerro ym. 2017). Taloudellisesti parempiosaisilla toimijoilla on puolestaan paremmat ja monipuolisemmat edellytykset luoda kotitalouden strategioita. Konservatiivisen ja liberaalin hyvinvointiregiimin alueilla strategioiden onkin todettu olevan vahvasti luokkasidonnaisia (ks. esim. Cveticanin \& Lavric 2017). Sosiaalidemokraattisessa (pohjoismaisessa) hyvinvointimallissa julkiset palvelut ja etuudet sen sijaan ovat olleet kattavampia ja osittain kaikkia kotitalouksia koskevia, kuten lapsilisä (Esping-Andersen 1990), ja perheet ovat voineet luottaa valtion tukeen. Artikkelissa tarkastelemme lapsiperheiden arjessaan kehittämiä selviytymisstrategioita suomalaisessa ja siten pohjoismaisen hyvinvointiregiimin kontekstissa.

Teoreettisena käsitteenä kotitalouden strategiat oli alunperin vastakkainen 1970- ja 1980-luvuilla yhteiskuntatieteissä vahvasti vaikuttaneen marxilaisen strukturalismin kanssa. Sen lähtökohtana on niin sanottu ruohonjuuritason näkökulma, jonka mukaan kotitaloudet voivat muovata ympäristöään sen sijaan, että ympäristö muovaa heitä (Wallace 2002). Kotitalouden strategioiden viitekehys nojaa erityisesti Bourdieun strategian käsitteeseen, jonka mukaan ihminen voi vaikuttaa valintoihinsa strategisesti sen sijaan että kulttuurinen tausta ohjaisi täydellisesti 
tämän toimintaa. Bourdieun mukaan strategiat ovat määrätietoista mutta osaksi tiedostamatonta toimintaa, ja ne edellyttävät toimiakseen kulttuurista ja taloudellista pääomaa (Cveticanin ym. 2014).

Tässä artikkelissa tarkoitamme kotitalouden strategioilla hyvinvointia ylläpitäviä taloudellisia, psyykkisiä ja sosiaalisisia järjestelyjä (Wallace 2002; ks. myös Törrönen 2014), jotka perustuvat perheiden sosiaaliseen, kulttuuriseen ja taloudelliseen pääomaan (Cveticanin \& Biresev 2012). Sovellamme kyseistä käsitettä bourdeaulaisen pääomajaottelun keinoin. Sosiaalista pääomaa voidaan tässä yhteydessä tarkastella kahdesta eri näkökulmasta: luottamukseen rakentuvan yhteisöllisen sosiaalisen pääoman (esim. Putnam 2000; Coleman 1988) sekä bourdieulaisen yksilöllisen sosiaalisen pääoman kautta. Putnamin näkemyksessä korostuu, ettei sosiaalista verkostoa rakenneta jonkin päämäärän saavuttamiseksi, vaan luottamuksen ja siten turvallisuuden tunteen ja osallisuuden kasvattamiseksi (Putnam 2000; Siisiäinen 2003; Nygård 2013). Bourdieu korostaa yksilön mahdollisuutta valita verkostonsa nimenomaan hyötymistarkoituksessa (resurssina), jonka ryhmän sisäinen solidaarisuus mahdollistaa (Bourdieu 1986; Siisiäinen 2003).

Käsitämme kulttuurisen pääoman Bouerdieun tulkinnan mukaisesti kasvatuksen ja koulutuksen kautta omaksuttuina asenteina, kompetenssina ja toimintatapoina (ks. Alasuutari 1997; Bourdieu 1986). Esimerkiksi Michèle Lamont ja Annette Lareu (1988) toteavat asenteiden ja käyttäytymisen olevan osa kulttuurista pääomaa. Kulttuurista pääomaa leimaavat aina olosuhteet, joissa se on saavutettu (Bourdieu 1986). Näin sen voi tulkita alueelliseen kulttuuriin liittyväksi toimintataipumukseksi. Tämän artikkelin kontekstissa kulttuurisen pääoman voidaan katsoa liittyvän myös sosiaaliseen pääomaan, sillä tutkimusten mukaan Pohjanmaalle alueena ja erityisesti suomenruotsalaiselle kulttuurille on ominaista sosiaalisten verkostojen vahvuus (Нyyppä \& Mäki 2001a; Reini \& Nyqvist 2017).

Myös taloudellinen pääoma on merkityksellinen kotitalouden strategioissa. Se koostuu yksilön resursseista, joko rahallisesta tai kiinteän omaisuuden muodossa olevasta pääomasta (Bourdieu 1986), ja sitä voitaneen pitää Bourdieun hahmottelemista pääomista yksiselitteisimpänä. Sekä sosiaalinen, kulttuurinen että taloudellinen pääoma kulkevat osittain lomittain, ja siten niitä on paikoin vaikea erottaa toisistaan.

\section{TUtKIMUSMENETELMÄT JA AINEISTO}

Empiirinen aineistomme koostuu talven 2016-2017 aikana tehdyistä 22 pohjanmaalaisen lapsiperheen laadullisista haastatteluista. Tutkimuksen alueellisen rajauksen teimme sen perusteella, että Pohjanmaa alueena on usein jäänyt vastaavien tutkimusten ulkopuolelle sitä leimaavan keskimääräistä korkeamman elintason ja esimerkiksi vahvan sosiaalisen pääoman vuoksi (Hyyppä \& Mäki 2001a; 2001b; Reini \& Nyqvist 2017). Tässä mielessä aluetta voi pitää "epätodennäköisenä tapauksena" (Flyvjberg 2006), jossa perheiden hyvinvoinnin ongelmat eivät ole kaikkein todennäköisimmin löydettävissä, mutta josta tehdyt havainnot ovat paremmin yleistettävissä kuin ilmeisem- 
män tapauksen kohdalla. Ajatuksena on, että jos ilmiötä koskevat esioletukset osoittautuvat paikkaansa pitäviksi tapauksessa, jossa ne eivät ole kaikkein ilmeisimmin vahvistettavissa, ne pätevät erittäin todennäköisesti myös ilmeisimpiin tapauksiin. Toisin sanoen, jos kotitalouden strategiat osoittautuvat keskeisiksi julkisen tuen paikkaajiksi keskimääräistä korkeamman elintason alueella, niiden voi olettaa olevan vähintään yhtä keskeisiä pienemmän elintason alueilla. Alueelta kuitenkin löytyy myös huonosti voivia ja taloudellisen epävarmuuden keskellä eläviä perheitä (esim. Turunen 2013; Kivimäki ym. 2014). Ensisijaisesti halusimme nostaa näiden perheiden tilanteen tarkasteltavaksi huolimatta mielikuvasta Pohjanmaasta hyvinvoivana maakuntana. Lisäksi maakunta muodosti maantieteellisine etäisyyksineen hallittavissa olevan alueen, jolloin haastattelumatkat eivät muodostaneet kohtuuttoman pitkiksi. Kaksikielinen alue mahdollisti sekä suomen- että ruotsinkielisten perheiden osallistumisen tutkimukseen.

Käytimme aineiston valinnassa harkinnanvaraista otosta esittämällä haastattelupyynnössä toiveen, että haastateltavaksi suostuvat perheet olisivat kokeneet yhteiskunnan taloudellisten muutosten vaikuttaneen elämäänsä. Haastateltavat tavoitettiin maakuntalehtien ja -radion sekä Facebookin välityksellä ohjeistuksella: "Haluatko kertoa tarinasi; millaista on arki, kun taloudesta jatkuvasti leikataan". Näin ollen tutkimukseen osallistuvilta ei edellytetty mitään tiettyä tulotasoa tai perhetilannetta. Tarkoituksena oli tavoittaa mahdollisimman erilaisia perheitä, jotka halusivat kertoa arjestaan ja tilanteestaan. Lisäksi sovelsimme niin sanottua lumipallotekniikkaa, jolloin mukana olleet perheet kertoivat myös tuttavaperheiden mahdollisesta halukkuudesta osallistua tutkimukseen. Perheiden lukumäärä määräytyi aineiston saturaation perusteella eli sen alkaessa toistaa itseään (Eskola \& Suoranta 1998).

Haastateltavien perhetilanteet olivat hyvin erilaisia yksinhuoltajaperheistä kahden työssäkäyvän vanhemman perheisiin ja yhden lapsen perheistä monilapsisiin perheisiin. Heidän tilanteensa ja arjen haasteensa vaihtelivat perhettä kohdanneesta sairaudesta työttömyyteen tai palvelujen saatavuuteen. Perheiden sosioekonominen asema vaihteli tukien varassa tai köyhyysrajan alapuolella elävistä hyvätuloisiin ja perheisiin, joilla oli palkkatulojen lisäksi esimerkiksi säästöjä tai sijoituksia. Vanhempien koulutustaso vaihteli opiskelijoista ja ammatillista koulutusta vailla olevista korkeakoulututkinnon suorittaneisiin. Heidän työsuhteensa puolestaan vaihtelivat lyhyistä määräaikaisuuksista ja osa-aikatyöstä vakituisiin asiantuntijatehtäviin. Haastatteluihin osallistui 17 äitiä, kolme isää ja kaksi pariskuntaa. Äitien suurempi halukkuus osallistua haastatteluihin voi johtua siitä, että kulttuurisesti kodin piiri mielletään naisten alueeksi (Kinnunen 2017). Lisäksi äitien on todettu kokevan jossain määrin enemmän huolta esimerkiksi lasten hyvinvoinnista verrattuina isiin (Halme \& Perälä 2014), minkä vuoksi he mahdollisesti myös herkemmin haluavat jakaa kokemuksiaan arjesta. Huolimatta äitien suuresta osuudesta isiin ja pariskuntiin verrattuna, haastatteluissa keskusteltiin perheestä kollektiivisena toimijana sekä käsiteltiin jo- 
kaisen perheenjäsenen jaksamista. Näin ollen käsittelemme analyysissämmekin haastateltuja perheinä, silloin kun keskustelu on koskettanut perhettä kokonaisuudessaan eikä pelkästään haastateltavan (äidin tai isän) tilannetta.

Haastatteluista 20 toteutti Marja Lindberg ja kaksi Mikal Nygård. Haastattelut suoritettiin joko perheiden kodeissa tai muussa soveltuvassa paikassa, kuten kirjastossa. Haastattelut nauhoitettiin perheiden suostumuksella, ja ne kestivät 1-2 tuntia. Nauhoitukset litteroitiin. Haastattelut olivat laadullisia, puolistrukturoituja teemahaastatteluja, ja kysymykset laadittu aikaisempia tutkimuksia hyödyntäen (Lammi-Taskula \& Karvonen 2014; Ahrendt ym. 2015). Haastattelun teemat koskivat perheen taloudelliseen tilanteeseen, arjen jaksamiseen sekä lasten ja vanhempien hyvinvointiin liittyviä asioita. Lisäksi pidimme tutkimuspäiväkirjaa, johon kirjattiin perheiden kertomuksista välittyviä tunnelmia ja ajatuksia. Käytimme niitä tekemiemme tulkintojen ja haastattelutilanteiden muistikuvien tukena.

Aineiston analyysissa käytimme laadullista sisällönanalyysia (Hsieh \& Shannon 2005; Kaid 1989) N’Vivo (versio 10.2.2) -ohjelman avulla, koska tavoitteena oli löytää haastatteluista teemoja ja yhteneväisyyksiä perheiden keinoista selvitä arjessaan. Analyysin ensimmäisessä vaiheessa koodasimme haastatteluaineistoa etsimällä mainintoja, jotka kuvaavat perheiden arjessaan kokemia riskejä ja haasteita. Näin hahmotimme tilanteet, joissa lapsiperheet elävät ja asiat, jotka he kokevat haasteellisina. Toisessa vaiheessa pilkoimme riskit selviytymisstrategioiksi analysoimalla perheiden keinoja selvitä arjen haasteista. Analyysin kolmannessa ja samalla viimeisessä vaiheessa luokittelimme selviytymisstrategiat Bourdieun pääomajaottelun mukaisesti sosiaalisen, kulttuurisen ja taloudellisen pääoman kategorioihin. Seuraavaksi kuvaamme analyysin keskeisimmät tulokset näiden pääomittain luokiteltujen kategorioiden mukaisesti.

\section{KOTITALOUdEN STRATEGIAT LAPSIPERHEIDEN ARJESSA}

Haastattelujen perusteella lapsiperheet kohtaavat arjessaan monenlaisia sekä taloudellisia että henkistä hyvinvointia uhkaavia riskejä. Yhtäältä valtio pyrkii tukemaan ja vahvistamaan perheiden taloutta ja hyvinvointia esimerkiksi varsin avokätisen tukijärjestelmän avulla. Tällöin suunnitellusti tapahtuvat muutokset perheiden arjessa, kuten esimerkiksi vanhempainvapaa, voidaan kattaa joko perheiden omien säästöjen tai julkisten tukien avulla, koska kyse on tilapäisestä notkahduksesta tai muutoksesta. Toisaalta äkilliset, suunnittelemattomat muutokset, kuten sairaus, työttömyys tai avioero, voivat puolestaan ajaa perheet kriisiin ja aikaansaada köyhyyttä, eriarvoisuutta tai muuta pahoinvointia. Tällaisissa tilanteissa valtion tukimuodot eivät usein enää riitä kattamaan ja paikkaamaan aiheutunutta notkahdusta (ks. Törrönen 2014; Cveticanin 2012). Kun hyvinvointivaltion tukimuodot eivät enää riitä suojaamaan lapsiperheitä sosiaalisilta riskeiltä, nämä joutuvat turvautumaan omiin kotitalouden strategioihinsa. 
Sosiaalinen pääoma - luottamusta ja turvaa verkostosta

Perheiden sisäisistä voimavaroista ja selviytymiskeinoista keskeisimpiä ovat erilaiset sosiaalisen verkoston varaan rakennetut tukimuodot (ks. esim. Cveticanin 2012; Cveticanin \& Lavric 2017). Aineistossa tulee esiin kahdenlaisia sosiaalisen verkoston merkityksiä. Yhtäältä sosiaalinen verkosto merkitsee perheille luottamusta ja turvaa jo pelkällä olemassaolollaan (Putnam 2000; Coleman 1988). Toisaalta sosiaalinen verkosto on rakentunut suurilta osin hyötymistarkoituksessa (Bourdieu 1986): haastateltavat kertoivat usein luottavansa siihen, että heidän sosiaalisesta verkostostaan löytyy tarvittava apu ja tuki arjen tilanteisiin.

Haastateltavat käsittivät kysymyksen sosiaalisesta verkostosta liittyvän joko ystäväpiiriin tai suvun ja erityisesti isovanhempien olemassaoloon. Sosiaalisen verkoston nähtiin tarjoavan joko taloudellista apua ja tukea käytännön arjen jaksamisessa tai sitten enemmän vertaistukea tai mahdollisuutta irrottautua arjen kuvioista kotona. Näistä ensimmäinen ryhmä painottui selkeästi suvun ja erityisesti isovanhempien tarjoamaan tukeen toisen ryhmän liittyessä enemmänkin ystäväpiiristä saatavaan tukeen. Ystäväpiirin laajuuteen vaikutti esimerkiksi käytettävissä oleva vapaaaika. Vanhemmat saattoivat rajoittaa kontaktejaan sosiaaliseen verkostoonsa ajankäytön priorisoimiseksi. Tätä tapahtui erityisesti perheissä, joissa vanhemmat olivat työssäkäyviä. Sosiaalisen pääoman jakautumisesta perheiden välillä ei juurikaan voinut tehdä päätelmiä liittyen perheiden kokoonpanoon tai lapsilukuun.
Osa perheistä mainitsi, ettei heillä ole minkäänlaista sosiaalista verkostoa käytettävissään. Heidän kohdallaan korostuivat muut kotitalouden strategiat ja kolmannen sektorin rooli. Kieliryhmiä verrattaessa enemmistö tässä ryhmässä olevista perheistä oli suomenkielisiä. Maantieteellinen etäisyys sukuun vaikuttaa perheiden mahdollisuuteen hyödyntää esimerkiksi isovanhempien tarjoamaa apua. Lisäksi hyödyntämismahdollisuuteen vaikuttavat isovanhempien ikä ja terveydentila sekä isovanhempien mahdollisten muiden lastenlasten lukumäärä. Osa perheistä kertoi saavansa satunnaisesti jonkinlaista tukea, mutta vain äärimmäisessä hädässä. He kuitenkin luottivat siihen, että tilanteen mennessä oikein pahaksi apua löytyy. Myös näiden perheiden enemmistö on suomenkielisisiä perheitä. Tässä yhteydessä voidaan tukeutua kieliryhmien kulttuurisia eroja koskeviin tulkintoihin (esim. Hyyppä \& Mäki 2001a; Reini \& Nyqvist 2017). Näiden mukaan sosiaaliseen verkostoon turvautuminen on ominaista erityisesti suomenruotsalaiselle kulttuurille, kun taas suomenkielisen Pohjanmaan kulttuuria leimaa tietynlainen "itsellisyyden" tavoittelu (Zimmerbauer 2008) ja omillaan pärjäämisen eetos, eikä avun pyytäminen perheen ulkopuolelta ole itsestäänselvyys:

No siinä on ehkä se tavallaan sellainen puoli, että ei haluaisi niitä omaisiakaan tai omaa äitiä niinkun liiaksi kuormittaa. Että tavallaan mä koitan sitten miettiä niinku sitä, että mikä olis niinku sopiva määrä, että mitä voi niinkun mummoa pyytää lapsia hoitamaan /... / kun mä ajattelen, että se pitäs olla se isovanhempisuhde lapsiin sillai, että se olis enemmän niinku sellanen iloa tuottava 
kuin että koettais se niinkun rasituksena se lasten hoitaminen (Nr.1)

Putnamilaisen sosiaalisen pääoman piirteitä voidaan nähdä kertomuksissa, joissa sosiaalinen verkosto tuottaa luottamusta ja siten vaikuttaa turvallisuuden tunteeseen. Huolimatta siitä, koetaanko todellista tarvetta turvautua sosiaaliseen verkostoon, haastateltavilla on vahva luottamus siihen, että tämä mahdollisuus on olemassa. Tämän lisäksi seuraavassa aineistolainauksessa voidaan nähdä kulttuurisen pääoman piirteitä haastateltavan nimetessä suomenruotsalaisen kulttuurinsa turvallisuuden tunnetta tuottavaksi. Tämä myös osoittaa, että sosiaalista ja kulttuurista pääomaa on ajoittain vaikea erottaa toisistaan (vrt. Hyyppä \& Mäki 2001a; Heikkilä 2008):

Och så vet jag inte i vilken mån det påverkar min känsla av trygghet $i$ den här ganska otrygga situationen, att vi är finlandssvenskar och jag vet att det finns ett sånt där bästa broder-nätverk, som liksom jag har kontakter och har räknat med. Ifall jag behöver ett jobb eller (barnet) behöver ett sommarjobb eller nånting så vet jag att vart jag ska skicka honom och räknar med att de tar sig an mig för att de känner mina föräldrar eller nånting. (Nr.16)

Bourdieulaisen sosiaalisen pääoman piirteitä sen sijaan tulee esiin ryhmässä, jossa enemmistönä ovat ruotsinkieliset perheet. Nämä perheet kertoivat omaavansa vahvan sosiaalisen verkoston, joka koostuu pääosin isovanhemmista. Sosiaaliselta verkostolta saatu tuki on sekä taloudellista (rahan lainaamista, lapsille ostettuja hyödykkeitä, matkoja ym.) että arjen jaksamista ylläpitävää (lap- senvahtina toimiminen, harrastusten ja "oman ajan" mahdollistaminen), kuten seuraavista aineistolainauksista voidaan havaita:

/.../ om man tänker /.../ att de som hjälper och sköter och sådant så då är det närmast min mamma kanske och nu som då och mina svärföräldrar nog. Min mamma har nog hjälpt oss, trots att hon är ensam så har hon hjälpt oss mycket som att köpa saker åt barnen och i somras var vi till [platsnamn] och det betalade hon (Nr.18)

/.../ min mamma är till exempel barnvakt åt vårt barn en gång $i$ veckan så att min man och jag kan fara på kaffe eller nånting och liksom hitta varann / . . / vi sku inte tror jag hinna prata liksom fulla meningar åt varann, utan det så (Nr.16)

Tässä ryhmässä näkyy selvästi suhtautuminen sosiaaliseen verkostoon hyötymistarkoituksessa. Edellä mainittujen tukimuotojen lisäksi isovanhemmat auttoivat monessa perheessä subjektiivisen päivähoito-oikeuden rajaamisesta aiheutuvien päivähoito-ongelmien ratkaisemisessa (HE 80/2015).

Arjen jaksamisessa haastateltavia auttoi myös vertaisilta saatu tuki, erityisesti tilanteissa, joissa perhettä oli kohdannut sairaus tai joissa lapsilla oli erityistarpeita. Tällaista tukea perheet olivat saaneet joko järjestäytyneemmin erilaisista vertaistukiryhmistä tai samanlaisessa elämäntilanteessa olevilta ystäviltä.

Paras on varmaan niinku tämmönen toisen erityislapsiperheen äiti. Että me puhutaan samaa kieltä ja hänen kanssaan pystyy sitten ihan niinkun kaikesta semmosesta mieltäpainavasta ja sem- 
mosesta askarruttavasta asiasta niinku puhumaan. Et synkimmätki ajatukset voi niinku toisen kanssa jakaa ja kertoa toinen ymmärtää sen, että miksi susta tuntuu tolta (Nr.7)

Myös kolmannen sektorin rooli näyttäytyi varsin voimakkaana julkisten palveluiden ollessa riittämättömiä. Näin erityisesti perheissä, joissa ei ollut sosiaalisen verkoston muodostamaa turvaa. Kolmas sektori ja seurakunnat tarjosivat sekä taloudellista apua että erilaista kerhotoimintaa, mahdollisuuden rakentaa sosiaalista verkostoa ja saada vertaistukea (esim. Teperi ym. 2006; Grönlund \& Juntunen 2006; Kinnunen 2009).

Sittenhän mä sain sillon vuosi sitten, kun mä olin eronnu /.../ niin se ensimmäinen joulu, niin mä sain [yhdistys] sillon niinkun, mä olin käyny leipäjonossa / .../ Niin ne jostain syystä sitte päätti antaa mulle niinkun heidän vuoden, tämmösen niinkun, joulumuistamisen, että valitaan aina joka vuosi yksi perhe /.../ me saatiin sillon eka jouluna sieltä ihan mahoton satsi, niinku lahjoja, tosi hyviä lahjoja, koruja, ihan koruja ja semmosia ja sitte ruokaa ja sitte vielä lisäksi joulukinkkuki tuli sieltä sillon. (Nr.15)

Kulttuurinen pääoma - taistelutahtoa ja periksiantamattomuutta

Lapsiperheiden toinen selkeä selviytymisstrategia on oikeuksien puolesta taisteleminen. Se voidaan tulkita kulttuuriseen pääomaan liittyvänä, koska "taistelutahto" ja periksiantamattomuus ovat nähtävissä osittain kulttuurisidonnaisena ja sosiaalisesti opittuna tapana tai elämänkatsomuksena (esim. Bourdieu 1986). Bourdieun (emt.) mu- kaan kulttuurista pääomaa leimaavat ne olosuhteet, joissa se on hankittu. Näin ollen taistelutahto ja periksiantamattomuus voidaan tulkita myös pohjanmaalaiseen kulttuuriin liittyvänä ominaispiirteenä, johon usein liitetään muun muassa yrittäjähenkisyys, rehellisyys, ahkeruus, itsellisyys ja itsepäisyys (esim. Salo ym. 2005; Zimmerbauer 2008; Turunen 2013; Kivimäki ym. 2014).

Palvelujen käyttäjien ja tukien saajien vastarintaa on tutkittu ennen kaikkea järjestäytyneemmässä ja erityisesti sosiaalisten liikkeiden muodossa tapahtuvana (esim. Reese 2011), mutta se voi olla myös arkisempaa ja jokapäiväistä vastarintaa heille tarjottuja sosiaalista asemaa, vastuuta ja toimintamahdollisuuksia kohtaan (Kingfisher 1997; Gilliom 2001; Autto 2012). Tässä yhteydessä oikeuksien puolustaminen on nimenomaan vähemmän organisoitua ja pienimuotoisempaa, perhekohtaista taistoa omien sosiaalisten oikeuksien puolesta. Joissakin perheissä oikeuksien puolustaminen oli jossain määrin pidemmälle vietyä. He olivat esimerkiksi lähteneet mukaan paikallispolitiikkaan ajamaan lapsiperheiden oikeuksia tai kirjoittaneet aktiivisesti paikallis- ja makuntalehtien yleisönosastoille esimerkiksi tukijärjestelmän jäykkyydestä. Näiden perheiden arkeen kuuluivat usein yksinhuoltajuus, sairaudet tai työttömyys. Suurimmassa osassa perheitä oikeuksien puolesta taisteleminen kuitenkin kosketti yksittäisiä perheenjäseniä tai kokonaisia perheitä, jotka esimerkiksi hakivat valituksella muutosta kielteiseen viranomaispäätökseen. Tämä strategia korostui perheissä, joissa joko vanhempi tai lapsi sairasti. Nämä haastateltavat kertoivat saavansa toistuvasti kielteisiä tuki- ja 
etuuspäätöksiä koskien esimerkiksi kunnan vammaispalveluihin liittyviä asunnon muutostöitä tai lapselle erikoissairaanhoidossa määrättyä kuntoutusohjausta. Tällaiset tilanteet olivat vaatineet asioiden ja oikeuksien laajaakin selvittelyä, lakeihin ja asetuksiin perehtymistä sekä "byrokratiaviidakon" tuntemista:

on tosi vaikea ollu niinku tämän sairauden vuoksi, suostua ensinnäki hakemaan mitään etuutta, sitte kun vihdoin viimein oot hakenu, niin sitte tulee, ettet sinä saakaan sitä. Sitte saat niin$\mathrm{ku}$ vähän anella sitä, voisiko sitä saada ja eikö se vähä niinku kuulus mulle. Ei kuulu. Ja sitte sä joudut vaatia, nyrkki pöytään, tämä kuuluu mulle. Ja siihen mennessä sä oot selvittäny ja vaikka ja mitä. (Nr.13)

Perheitä, jotka kokivat joutuvansa taistelemaan oikeuksiensa puolesta, yhdistivät pääasiassa terveysongelmat joko vanhemman pitkäaikaissairauden tai lasten erityistarpeiden muodossa. Sairaus vaikutti varsin suoraan perheiden taloudelliseen tilanteeseen. Tämän vuoksi näiden perheiden toimeentulo nojasi vahvasti julkisiin tukiin. Nämä perheet kuvasivat julkisia tukimuotoja ja hakuprosesseja byrokraattisiksi ja tiukoiksi. He kokivat joutuvansa taistelemaan sellaistenkin tukien puolesta, joihin heillä oli lainmukainen oikeus. Lisäksi palveluista ja oikeuksista ei heidän mukaansa tiedotettu, vaan useimmiten he saivat näistä tiedon lähipiiriltään tai vertaisryhmistä.

Se on ihan niinku järjetöntä välillä tuo, että tämmösistä niinku päivänselvistä asioista pitää tapella ja just sitten, että kyllä niinku monesti ihmetelty kaverin kans, että missä on se ennaltaehkäsevä juttu, että jos niinku näitäkään ei tarvis taistella ja tavallaan ne niinkun tulis mitä kuuluu, ilman että tarvii tosiaan hirveesti käyttää energiaa, niin se kyllä helpottais aika paljon. (Nr.8)

Och nog är det tungt ännu nog, eftersom man alltid ska kämpa för sina rättigheter. Alltså just detta med ekonomiska möjligheter, de borde informera, ge information om vad du har rätt till eller vad du kan göra /.../ Och just det där att det ska vara lättare att söka hjälp. Som just till socialen och om det är riktigt eländigt /.../ man ska måste kun gå dit utan att det är riktigt eländigt. (Nr.20)

Haastateltavat kertoivat joutuvansa toistuvasti taistelemaan oikeuksiensa puolesta julkisen vallan edustajia vastaan. Esimerkkeinä voidaan mainita sairauspäivärahan saaminen lääkärin toteamaan työkyvyttömyyteen; lapsen omaishoidontuen uudelleenarviointi ja evääminen huolimatta tilanteen muuttumattomuudesta ja kuntoutuspäätöksessä vahvistetun palvelun evääminen kuntatasolla. Toinen taistelutahtoa ja -tarvetta synnyttänyt tekijä oli työttömyys tai työttömyyden uhka sekä esimerkiksi lyhyiden, osa-aikaisten työsuhteiden aiheuttama työttömyyskorvauksen karenssipäätös ja siitä seuraava taloudellinen epävarmuus. Vastaavat tilanteet ovat vaikuttaneet voimakkaasti perheiden kokemaan luottamukseen. Esimerkiksi seuraavassa aineistolainauksessa tulee esiin, miten haastateltavan hankalassa suhteessa työvoimatoimistoon hyvinvointivaltion ammattilainen näyttäytyy pikemminkin arjessa selviy- 
tymistä vaikeuttavana kuin tukevana (ks. myös Liikanen 2017; Efendic 2017):

että tää on ollu aika kauheeta ton työvoimatoimiston kanssa, niinkun nää, että mun kaikki aktiivisuus on aina rangaistu, että kun opiskelen, rangaistaan, kun teen työtä, niin rangaistaan, että aika traumaattinen paikka (Nr.15)

Pääsääntöisesti kaikki sellaiset perheet, jotka saivat valtion tukiin ja etuuksiin liittyviä kielteisiä päätöksiä, hakivat päätöksiin muutosta valittamalla. Tämä koettiin jopa vallalla olevaksi ja tukijärjestelmään kuuluvaksi ominaisuudeksi, joka myös murensi perheiden luottamusta valtiota kohtaan (ks. myös Liikanen 2017). Vain yksittäisissä tapauksissa perheissä tyydyttiin kielteiseen päätökseen, koska esimerkiksi terveydellinen tilanne teki valitusprosessin läpiviemisen mahdottomaksi. Näissä tilanteissa tukea oli kuitenkin saatavissa sosiaaliselta verkostolta, jolloin haastateltava ei kokenut jäävänsä täysin oman onnensa nojaan.

Luottamusta sekä kulttuurista pääomaa voi tarjota myös uskonto, jonka jotkut perheistä mainitsivat voimavarakseen. Pohjanmaa on varsin uskonnollista aluetta (Kääriäinen ym. 2003), ja osalle perheistä oli luontevaa turvata uskontoon vaikeissa elämäntilanteissa. He kertoivat esimerkiksi pahan paikan tullen ristivänsä kätensä tai uskovansa "korkeimman johdatukseen" ja näin kokevansa luottamusta tulevaa ja omia voimavarojaan kohtaan:

Ja siellä taustalla on sitten uskonto tavallaan yks semmonen tärkeä asia /.../ en voi sanoa, että olisin niinkun kovin harras uskovainen, mutta ehkä se pe- rusluottamus siihen, että elämä kantaa ja että tavallaan se, että vaikka nyt on vaikeeta niin sitte jossain vaiheessa taas voi olla helpompaa. (Nr.1)

Taloudellinen pääoma - selviytymistä talouden notkahduksista

Kotitalouden strategioiden kolmannen ryhmän muodostavat erilaiset taloudelliset järjestelyt, joita voidaan tarkastella Bourdieun taloudellisen pääomatyypin valossa. Nämä järjestelyt ovat lähimpänä kotitalouden strategioiden käsitteen alkuperäisintä sisältöä, joka koskee nimenomaan kotitalouksien taloudellisia järjestelyjä julkisten tukien ollessa riittämättömiä (Wallace 2002; Cveticanin ym. 2014; Katz-Gerro ym. 2017).

Omaisuuden myyminen on yksi keino helpottaa taloudellista tilannetta hetkellisesti. Haastateltavien kuvauksissa tämä hahmottui tilapäisenä ratkaisuna, johon turvauduttiin silloin, kun käytettävissä olevat taloudelliset resurssit eivät riittäneet tyydyttämään perustarpeita. Jotkin yksinhuoltajaperheistä olivat realisoineet omaisuutta, jota eivät pitäneet välttämättömänä, kuten keräilyastioita, mutta jolla saattoi olla tunnearvoa. Myös elintason laskeminen, kuten auton vaihtaminen halvempaan työttömyyden kohdatessa, oli yksi tapa helpottaa taloudellista tilannettaan hetkellisesti (ks. esim. Salmi ym. 2014):

/.../ då jag till exempel sålde en dyrare bil än vad jag har i dagens läge, så lämnade det en mellanskillnad med pengar som vi har kunnat använda i det dagliga, betala räkningar och sånt, men sen då de pengarna är slut så vet jag inte vad vi ska hitta på (Nr.18) 
Seuraavassa lainauksessa työssäkäyvä yksinhuoltaja kertoo perheen arjen strategioihin kuuluvan paitsi tavaroiden myymisen myös ruokakuluissa säästämisen:

mä myin /.../ muumimukeja, semmosia näitä keräilymukeja /.../ että mä sain jostain sitä ylimäärästä rahaa, että mä pystyin hankkimaan talvivarusteita ja tämmöstä, että sillon oli pakko keksiä tämmösiä. Ja tinkiä omista menoista ja ruoka ja kaikki tämmönen, jauhelihaa ja keittoja ja makaronilaatikkoo, siis et kyllähän sitä pienelläkin pärjää, kun suunnittelee sen. Mutta sitten ei oo mihinkään yllätyksiin, ei oo varaa (Nr.7)

Taloudellinen tuki liittyy vahvasti myös sosiaaliseen verkostoon ja näin ollen sosiaaliseen pääomaan (ks. esim. Cveticanin ym. 2014). Perheissä, joissa oli jo vanhempia lapsia, lasten kesätyössä ansaitsemia rahoja käytettiin perheen hyvinvoinnin tukena. Lapset maksoivat itse omat vaatteensa ja vapaa-ajan menonsa tai lainasivat vanhemmilleen rahaa. Tätä tapahtui erityisesti monilapsisissa perheissä, joissa rahatilanne oli tiukka esimerkiksi vanhemman sairauden vuoksi. Rahaa voitiin lainata myös muulta sosiaaliselta verkostolta, pääsääntöisesti lähisuvulta. Pienituloisissa perheissä lasten eriarvoisuus korostui esimerkiksi erilaisissa hankinnoissa, merkkivaatteissa tai kännykän mallissa. Lapset eivät saaneet asioita, joita heidän ystävillään on - mopoista tai ajokorteista puhumattakaan. Taloudellisten vaikeuksien kanssa kamppaileville perheille kyseiset investoinnit olivat aivan liian suuria ja kalliita. Tällöin vaihtoehdoksi jäi, että lapset hankkivat ne itse.
Moni perhe pyrki tekemään asioita itse niin pitkälle kuin taidot ja resurssit riittivät esimerkiksi ompelemalla vaatteita itse ja säästämällä auton huoltokuluissa omien kykyjen rajoissa:

jos auto hajoo, niin sit mies korjaa. Ettei meillä mihinkään korjaamolle viedä autoja. Et niinku se on sitte itte korjattava niin pitkälle, kun pystyy. (Nr.11)

Lisäksi taloudellisesti tiukilla olevat haastateltavat kertoivat kasvattavansa kesäisin perunaa, vihanneksia ja marjoja sekä poimivansa syksyisin sieniä (ks. esim. Nelson \& Smith 1999). Myös lasten harrastuksista säästäminen sisältyy taloudelliseen pääomaan nojaaviin kotitalouden strategioihin. Haastateltavat olivat korvanneet taloudellisia kustannuksia aiheuttavia harrastuksia esimerkiksi retkeilemällä luonnossa. Näin tapahtui erityisesti monilapsisissa perheissä, joissa kaikkien lasten harrastuksiin ei ollut varaa. Perheet kokivat epäreiluna, jos vain osa lapsista sai mahdollisuuden harrastaa.

Useat äidit kertoivat tinkivänsä omista kuluistaan, kuten kampaamokäynneistä, harrastuksista tai vaatehankinnoistaan taatakseen perheensä perustarpeet ja erityisesti lastensa hyvinvoinnin (ks. myös Halme \& Perälä 2014). Vanhemmat tinkivät jopa omista välttämättömistä lääkkeistään, kuten eräs isä seuraavassa lainauksessa kertoo. Lääkeostoissa kalenterivuoden alussa perittävä omavastuuosuus saattoi olla liian suuri, jolloin lääkkeet oli senkin vuoksi jätettävä ostamatta:

Och även jag har ju lämnat bort, för jag har den där [medicinen], så då jag tar ut den så måste jag ju betala självris- 
ken på 650 euro, det är ju bara en gång då per år, men det blir ju för det mesta januari, februari, då är riktigt eländigt. /.../ många gånger så har jag lämnat bort det, för att det är för stor utgift, man har inte möjlighet att ta ut det, utan man måste spara det till en annan månad (Nr.20)

Julkisten tukien leikkaukset, kuten esimerkiksi Kelan matkakustannuskorvausten omavastuuosuuden nostaminen (Kela 2016), vaikuttivat myös monen sairautta kohdanneen perheen arkeen erityisesti haja-asutusalueilla, joista matkat sairaanhoitopiirin palveluihin olivat pitkiä. Tämä asetti maaseudulla asuvat perheet eriarvoiseen asemaan kaupungeissa asuvien kanssa.

\section{LOPUKSI}

Artikkelimme tulosten perusteella lapsiperheiden luomien kotitalouden strategioiden merkitys on ilmeinen perheiden arjessa pärjäämisen ja jaksamisen kannalta, niin taloudellisesti kuin muutakin hyvinvointia ajatellen. Cveticanin ja kumppanit (2014) korostavat, että strategiat voivat kehittyä ainoastaan vakaassa yhteiskunnassa, jossa tavoitteena on laaja ja kattava tukijärjestelmä; heidän mukaansa useasti muuttuva järjestelmä ei edesauta yksittäisten strategioiden syntymistä (vrt. Wallace 2002). Artikkelimme tulosten perusteella kotitalouden strategiat ovat kuitenkin korostuneet Suomessa hyvinvointivaltion muutoksen yhteydessä, kuten lapsiperheiden tukijärjestelmän ja palveluiden kaventuessa. Lapsiperheiden pahoinvointi on ollut nähtävillä jo 1990-luvun laman jälkeisestä ajasta lähtien (esim. Lammi-Taskula \& Karvonen
2014; Törrönen 2014; Sundman 2016). Tutkimuksemme tulokset vahvistavat aikaisempien tutkimusten havaintoja perheiden eriarvoisuuden lisääntymisestä ja lapsiköyhyyden kasvusta (esim. Kiander 2001; Leinonen 2004; Ahrendt ym. 2015; Karvonen \& Salmi 2016). Esimerkiksi terveyspalveluiden alueellinen keskittäminen lisää eriarvoisuutta ja suosii keskuskaupungeissa asuvia.

Lapsiperheiden selviämisstrategioiden voidaan katsoa muuttuneen järjestelmällisemmiksi ja arkipäiväisemmiksi. Kulttuurisen pääoman alle luokittelemamme taistelutahto on ristiriitainen suhteessa yhteiskunnalliseen keskusteluun aktivointipolitiikasta (ks. esim. Karjalainen \& Keskitalo 2013), jossa sosiaalisten riskien, kuten työttömyyden tai sairauden kanssa kamppailevat, nähdään usein passiivisina toimijoina. Aineistomme perusteella voidaan todeta päinvastainen ilmiö, jossa ahdingossa elävät perheet nousevat taisteluun valtiota vastaan ja aktiivisesti puolustavat oikeuksiaan. Valtio näyttäytyy useissa tapauksissa enemmänkin vihollisena, mikä edelleen murentaa luottamusta julkisia tukia kohtaan (esim. Liikanen 2017). Hyvinvointivaltion laajentuminen antoi yksilöille mahdollisuuden pärjätä omillaan, kun he saattoivat luottaa valtioon perustoimeentulon ja yhdenvertaisten palvelujen tuottajana. Taloudellisten lamakausien säästöpolitiikan vaikutusten myötä yksilön omillaan pärjääminen on vaikeutunut ja esimerkiksi sosiaalisen verkoston merkitys puolestaan kasvanut. Tällaisessa tilanteessa kotitalouden strategiat korostuvat, ja ne voidaan nähdä hyvinvointipolitiikan rinnalle juurtuvina arjen selviytymisen keinoina. 
Lapsiperheiden hyvinvoinnin tutkimuksessa tulisikin kiinnittää huomiota julkisen tuki- ja palvelujärjestelmän ohella kotitalouden strategioihin, mikä auttaisi ymmärtämään hyvinvoinnin haasteita ja hyvinvoinnin rakentumiseen vaikuttavien tekijöiden moninaisuutta. Yhtenä tutkimustarpeena näemme lapsiperheiden kotitalouden strategioiden alueellisesti laajemman tarkastelun. Olisi mielenkiintoista tarkastella kotitalouden strategioita myös yhteiskuntaluokkien näkökulmasta, Bourdieun sosiaalisen kentän ja habituksen käsitteiden kautta Pohjoismaisessa hyvinvointiregiimissä. Tähän aineistomme ei antanut mahdollisuuksia. Lisäksi kotitalouden strategioiden eri osa-alueet, kuten taloudelliset ratkaisut, kaipaavat vielä yksityiskohtaisempaa tutkimusta.

\section{KirjallisuUs}

Ahrendt, Daphne \& Blum, Sonja \& Crepaldi, Chiara (toim.) (2015) Families in the economic crisis: Changes in policy measures in the EU. Luxembourg: Publications Office of the European Union.

Airio, Ilpo \& Niemelä, Mikko (2009) Perhetaustan yhteys aikuisiän köyhyyteen Suomessa 1995-2005. Sosiologia 46 (1), 3-19.

Alasuutari, Pertti (1997) Kulttuuripääoma summamuuttujan valossa. Sosiologia, 34 (1), 3-14.

Autto, Janne (2012) Päivähoitopolitiikka kamppailuna hyvinvointivaltiosta. Kentät, subjektiasemat ja oikeutukset. Acta Universitatis Lapponiensis. Rovaniemi: Lapin yliopistokustannus.

Autto, Janne \& Nygård, Mikael (2015) Johdanto: Mitä on hyvinvointivaltion kulttuurintutkimus? Teoksessa Janne Autto \& Mikael Nygård (toim.) Hyvinvointivaltion kulttuurintutkimus. Rovaniemi: Lapin yliopistokustannus.

Bourdieu, Pierre (1986) The forms of capi-
tal.Teoksessa: John G. Richardson (toim.) Handbook of theory and research for the sociology of education. New York: Greenwood Press, 241-258.

Coleman, James S. (1988) Social capital in creation of human capital. American Journal of Sociology 94, 95-120. https:// doi.org/10.1086/228943

Cveticanin, Predrag (toim.) (2012) Social and Cultural Capital in Serbia. Serbia: Centre for Empirical Cultural Studies of South-East Europe.

Cveticanin, Predrag \& Biresev, Ana (toim.) (2012) Social and cultural capital in Western Balkan societies. Centre for empirical cultural studies of South-East Europe. Belgrade: The institute for philosophy and social theory of the University of Belgrade.

Cveticanin, Predrag \& Lavric, Miran (2017). Typology of Households Strategies of Action in Four Countries of Southeastern Europe in a Period of Economic Crisis. Household strategies in the period of economic crisis. Südosteuropa 65 (3), 459-494. https://doi.org/10.1515/ soeu-2017-0031

Cveticanin, Predrag \& Spasic, Ivana \& Gavrilovic, Danijela (2014) Strategies and tactics in social space: The case of Serbia. Social Science Information 53 (2), 213-239. https://doi. org/10.1177/0539018413517182

Eduskunta (2016) Lapsilisiä leikataan. Tiedotteet 23.11.2016. https://www.eduskunta.fi/FI/tiedotteet/Sivut/Lapsilisaleikkaukset.aspx. Luettu 21.3.2018.

Efendic, Adnan \& Cveticanin, Predrag \& Kumalic, Ismet (2017) Thriving and Surviving Activites of Households During the Crisis Period. Empirical Evidence from Southeastern Europe. Household strategies in the period of economic crisis. Südosteuropa 65 (3), 495-519. https://doi.org/10.1515/soeu-20170032

Eriksen, Lise (2015) Leipäjonot sanomalehtijulkisuuden keskusteluissa. Teoksessa Janne Autto \& Mikael Nygård (toim.) Hyvinvointivaltion kulttuurintutkimus. Rovaniemi: Lapin yliopistokustannus, 246-277.

Eskelinen, Niko \& Sironen Jari (toim.) (2017) Köyhyys - syitä ja seurauksia. 
Helsinki: Suomen köyhyyden ja syrjäytymisen vastainen verkosto EAPN-Fin.

Eskola, Jari \& Suoranta, Juha (1998) Johdatus laadulliseen tutkimukseen. Tampere: Vastapaino.

Esping-Andersen, Gösta (1990) The Three Worlds of Welfare Capitalism. Oxford: Polity Press.

Flyvjberg, Bent (2006) Five Misunderstandings About Case-Study Research. Qualitative Inquiry 12 (2), 219-245. https:// doi.org/10.1177/1077800405284363

Fontaine, Laurence \& Schlumbohm, Jürgen (2000) Household Strategies for Survival: An Introduction. International Review of Social History 45 (8), 1-17. https:// doi.org/10.1017/S0020859000115263

Gershuny, Jonathan I. (1978) After Industrial Society: The Emerging Self-Service Economy. London: Macmillan. https:// doi.org/10.1007/978-1-349-15898-0

Gershuny, Jonathan I. \& Pahl, Ray E. (1979) Work Outside Employment: Some Preliminary Speculations. New Universities Quarterly 34 (1), 120-35. https:// doi.org/10.1111/j.1468-2273.1979. tb01252.x

Gilliom, John (2001). Overseers of the Poor. Surveillance, Resistance, and the Limits of Privacy. Chicago: The University of Chicago Press.

Grönlund, Henrietta \& Juntunen, Elina (2006) Diakonia hyvinvointijärjestelmän aukkojen tunnistajana ja paikkaajana. Teoksessa Elina Juntunen, Henrietta Grönlund \& Heikki Hiilamo (toim.) Viimeisellä luukulla - tutkimus viimesijaisen sosiaaliturvan aukoista ja diakoniatyön kohdentumisesta. Helsinki: Kirkkohallitus, 180-198.

Halme, Nina \& Perälä, Marja-Leena (2014) Lapsiperheiden huolet ja avunsaanti. Teoksessa Johanna Lammi-Taskula \& Sakari Karvonen (toim.) Lapsiperheiden hyvinvointi 2014. Helsinki: Terveyden ja hyvinvoinnin laitos, 216-226.

HE 80/2015. https://www.finlex.fi/fi/ esitykset/he/2015/20150080. Luettu 18.12.2017.

Heikkilä, Riie (2008) Bättre folk, bättre smak? Suomenruotsalainen itseidentifikaatio haastatteluaineiston valossa. Yhteiskuntapolitiikka 73 (5), 494-507.

Hsieh, Hsiu-Fang \& Shannon, Sarah E.
(2005) Three Approaches to Qualitative Content Analysis. Qualitative Health Research 15 (9), 1277-88. https://doi. org/10.1177/1049732305276687

Hyyppä Markku T. \& Mäki Juhani (2001a) Why do Swedish-speaking Finns have longer active life? An area for social capital research, Health Promotion International, 16 (1), 55-64. https://doi. org/10.1093/heapro/16.1.55

Hyyppä Markku T. \& Mäki Juhani (2001b), Individual-level relationships between social capital and self-rated health in a bilingual community, Preventive Medicine 32 (2),148-55. https://doi.org/10.1006/ pmed.2000.0782

Julkunen, Raija (2017) Muuttuvat hyvinvointivaltiot. Eurooppalaiset hyvinvointivaltiot reformoitavina. Jyväskylä: SoPhi.

Kaid, Lynda Lee (1989) Content Analysis. Teoksessa Philip Emmert \& Larry L. Barker (toim.) Measurement of communication behavior. New York: Longman, 197-217.

Karjalainen,Vappu \& Keskitalo, Elsa (toim.) (2013) Kaikki työuralle! Työttömien aktiivipolitiikka Suomessa. Helsinki: Terveyden ja hyvinvoinnin laitos.

Karvonen, Sakari \& Salmi, Minna (toim.) (2016) Lapsiköyhyys Suomessa 2010-luvulla. Helsinki: Terveyden ja hyvinvoinnin laitos.

Katz-Gerro, Tally \& Cveticanin, Predrag \& Leguina, Adrian (2017) Consumption and social change. Sustainable lifestyles in times of economic crisis. Teoksessa Maurie J. Cohen, Halina Szejnwald Brown \& Philip J. Vergragt (toim.) Social Change and the Coming of Post-Consumer Society. Theoretival advances and policy implications. New York: Routledge, 95-124. https://doi. org/10.4324/9781315630168-8

Kautto, Mikko (2001) Diverstity among Welfare States. Comparative Studies on Welfare State Adjustment in Nordic Countries. Helsinki: Stakes.

Kela (2016) Kela-korvauksiin muutoksia vuonna 2016. http://www.kela.fi/documents/10180/1169692/Esite_Laakekorvaus2016_VERKKO.pdf/f28546ecc3e2-4e1b-ab18-a19581ce5f7f. Luettu 18.12.2017.

Kiander, Jaakko (2001) Laman opetukset. 
Suomen 1990-luvun kriisin syyt ja seuraukset. Suomen akatemian tutkimusohjelma. VATT-julkaisuja 27:5. Helsinki: Valtion taloudellinen tutkimuskeskus.

Kingsfisher, Catherine (1997) Women in the American Welfare Trap. Philadelphia: University of Pennsylvania Press.

Kinnunen, Kaisa (toim.) (2009) Sairas köyhyys:Tutkimus sairauteen liittyvästä huono-osaisuudesta diakoniatyössä. Helsinki: Kirkkohallitus.

Kinnunen, Veera (2017) Tavarat tiellä. Sosiologinen tutkimus esinesuhteista muutossa. Rovaniemi: Lapin yliopisto.

Kivimäki, Hanne \& Luopa, Pauliina \& Matikka, Anni \& Nipuli, Suvi \& Vilkki, Suvi \& Jokela, Jukka \& Laukkarinen, Essi \& Paananen, Reija (2014) Kouluterveyskysely 2013, Pohjanmaan raportti. Helsinki: Terveyden ja hyvinvoinnin laitos. (THL)www.thl.fi/attachments/kouluterveyskysely/Maakuntaraportit/Pohjanmaa_2103.Pdf. luettu 17.11.2017.

Krok, Suvi (2009) Hyviä äitejä ja arjen pärjääiä - yksinhuoltajia marginaalissa. Acta Universitatis Tamperensis 1437. Tampere:Tampereen yliopisto.

Kääriäinen, Kimmo \& Niemelä, Kati \& Ketola, Kimmo (2003) Moderni kirkkokansa. Suomalaisten uskonnollisuus uudella vuosituhannella. Kirkon tutkimuskeskuksen julkaisuja 82. Tampere: Kirkon tutkimuskeskus.

Lainiala, Lassi (2014) Perhepolitiikka kriisin aikana, Perhebarometri 2014. Väestöntutkimuslaitos Katsauksia E 48/2014. Helsinki:Väestöliitto.

Lammi-Taskula, Johanna \& Karvonen, Sakari (toim.) (2014) Lapsiperheiden hyvinvointi 2014. Helsinki: Terveyden ja hyvinvoinnin laitos.

Lammi-Taskula, Johanna \& Salmi, Minna (2010) Lapsiperheiden toimeentulo lamasta lamaan. Teoksessa Marja Vaarama, Pasi Moisio \& Sakari Karvonen (toim.) Suomalaisten hyvinvointi 2010. Helsinki: Terveyden ja hyvinvoinnin laitos, 198-215.

Lamont, Michèle \& Lareau, Annette (1988) Cultural capital: Allusions, gaps and glissandos in recent theoretical developments. Sociological Theory 6 (2), 153168. https://doi.org/10.2307/202113

Leinonen, Jenni (2004) Families in struggle.
Child Mental Health and Family Wellbeing in Finland During the Economic Recession of the 1990s: The Importance of Parenting. Helsinki: Stakes.

Liikanen, Sanna-Liisa (2017) Köyhät ritarit. Luottamus köyhyyskirjoituskilpailuun osallistuneiden lapsiperheiden vanhempien kirjoituksissa. Helsinki: Diakoniaammattikorkeakoulu.

Nelson, Margaret K. \& Smith, Joan (1999) Working Hard and Making Do: Surviving in Small Town America. Berkeley: University of California Press.

Nygård, Mikael (2013) Socialpolitik i Norden. En introduktion. Lund: Studentlitteratur.

Oorschot, Wim van (2007) Culture and social policy: developing a field of study. International Journal of Social Welfare 16 (2), 129-239. https://doi.org/10.1111/ j.1468-2397.2006.00451.x

Pahl, Ray E. (1980) Employment, Work and the Domestic Division of Labour. International Journal of Urban and Regional Research 4 (1), 1-20. https:// doi.org/10.1111/j.1468-2427.1980. tb00349.x

Pahl, Ray E. (1984) Divisions of Labour. Oxford: Blackwell.

Perustuslakivaliokunta (2014). Perustuslakivaliokunnan lausunto 32/2014. Hallituksen esitys eduskunnalle laiksi lapsilisälain 7 S:n muuttamisesta. PeVL 32/2014 vp - HE 165/2014 vp. https://www. eduskunta.fi/FI/vaski/Lausunto/ Documents/pevl_32+2014.pdf. Luettu 21.3.2018.

Putnam, Robert D. (2000) Bowling alone. The Collapse and Revival of American Community. New York: Simon \& Schuster.

Reese, Ellen (2011) They Say Cutback, We Say Fight Back!: Welfare Activism in an Era of Retrenchment. New York: Russel Sage Foundation.

Reini, Kaarina \& Nyqvist, Fredrica (2017) Sense of mastery differences between working-age Swedish- and Finnishspeaking Finns: a population-based study, Scandinavian Journal of Public Health 45 (4), 404-410. https://doi. org $/ 10.1177 / 1403494817696183$

Roos, J.P. (2013) Taistelusta yhteistoimintaan - Pierre Bourdieu hyvinvointival- 
tionpuolustajana. Teoksessa Juho Saari, Sakari Taipale \& Sakari Kainulainen (toim.) Hyvinvointivaltion moderneja klassikoita. Helsinki: Diakonia-ammattikorkeakoulu, 135-150.

Salmi, Minna \& Lammi-Taskula, Johanna (2014). Lapsiperheiden vanhemmat työelämässä. Teoksessa Johanna Lammi- Taskula \& Sakari Karvonen (toim.) Lapsiperheiden hyvinvointi 2014. Helsinki: Terveyden ja hyvinvoinnin laitos, 26-37.

Salmi, Minna \& Lammi-Taskula, Johanna \& Sauli, Hannele (2014) Lapsiperheiden toimeentulo. Teoksessa Johanna Lammi-Taskula \& Sakari Karvonen (toim.) Lapsiperheiden hyvinvointi 2014. Helsinki: Terveyden ja hyvinvoinnin laitos, 82-105.

Salo, Kari \& Zimmerbauer, Kaj \& Suutari, Timo (2005) Eteläpohjalaisuuden tuottaminen sosiaaliemotionaalisessa sähköpostiviestinnässä. Elore 12 (2), 1-23.

Siisiäinen, Martti (2003) Yksi käsite, kaksi lähestymistapaa: Putnamin ja Bourdieun sosiaalinen pääoma. Sosiologia 40 (3), 204-218.

Sundman, Robert (2016) Mitä lama-ajan lapset opettivat? Tesso. https://tesso.fi/ artikkeli/mita-lama-ajan-lapset-opettivat. Luettu 21.3.2018.

Teperi, Juha \& Vuorekoski, Lauri \& Manderbacka, Kristiina \& Ollila, Eeva \& Keskimäki Ilmo (toim.) (2006) Riittävät palvelut jokaiselle. Näkökulmia yhdenvertaisuuteen sosiaali- ja terveydenhuollossa. Helsinki: Stakes.
Turunen, Minna (2013) Pohjanmaan väestö, sen hyvinvointi ja terveys sekä sosiaali- ja terveyspalvelujärjestelmän toimivuus. Kansalliseen vertailuun perustuvaa trenditietoa vuosilta 2005-2011. Vaasan yliopiston julkaisuja, selvityksiä ja raportteja 186.Vaasa:Vaasan yliopisto.

Törrönen, Maritta (2012) Sosiaalityö ja arkinen hyvinvointi. Vastavuoroisuuden dialektiikka. Janus 20 (2), 182-191.

Törrönen, Maritta (2014) Everyday happiness. The everyday life and well-being of families with children. Publications of the Department of Social Research 2014:3. Helsinki: Helsingin Yliopisto. https://doi.org/10.31885/2018.00005

Wallace, Claire (2002) Household Strategies: Their Conceptual Relevance and Analytical Scope in Social Research. Sociology 36 (2), 275-292. https://doi. org/10.1177/0038038502036002003

Wallace, Claire \& Pahl, Ray E. (1986) Polarisation, Unemployment and All Forms of Work. Teoksessa Sheila Allen, Alan Waton, Kate Purcell \& Stephen Wood (toim.) The Experience of Unemployment. London: Macmillan, 116-33.

Westholm, Erik (2017) The prospects for Swedish farming: agrarian change and household strategies. https://www.slu. se/en/departments/urban-rural-development/research/rural-development/ projects/prospects/ Luettu 17.11.2017.

Zimmerbauer, Kaj (2008) Alueellinen imago ja identiteetti liikkeessä. Seinäjoki: Helsingin yliopisto, Ruralia-instituutti. 